\title{
Development of Rural Herbal Entrepreneurship in Malaysia
}

\author{
Kamal Chandra Paul ${ }^{1}$, Azimi Hamzah ${ }^{1}$, Bahaman Abu Samah ${ }^{1}$, Ismi Arif Ismail ${ }^{1} \&$ Jeffrey Lawrence D'Silva $^{1}$ \\ ${ }^{1}$ Laboratory for Citizenship and Leadership, Institute for Social Science Studies Universiti Putra Malaysia, \\ Malaysia \\ Correspondence: Jeffrey Lawrence D'Silva, Institute for Social Science Studies Universiti Putra Malaysia, \\ Malaysia.E-mail: jld@putra.upm.edu.my
}

Received: April 11, 2013

doi:10.5539/ijbm.v8n18p95

\author{
Accepted: July 17, 2013 \\ Online Published: August 20, 2013 \\ URL: http://dx.doi.org/10.5539/ijbm.v8n18p95
}

\begin{abstract}
The purpose of this research is to highlight the critical success and failure factors among rural Malay herbal entrepreneurs in Malaysia. As this was an exploratory research, a case study method was used as it gave an in-depth explanation on the issues regarding rural herbal entrepreneurship. This study was conducted in MAHA (Malaysia Agriculture, Horticulture \& Agritourism), Serdang, Selangor with ten herbal entrepreneurs - five successful entrepreneurs and five unsuccessful entrepreneurs. The result suggested that customer service know-how of the business and the past experience of the entrepreneur are the major key factors of success. On the other hand, failure factors are explored and the most crucial ones are the lack of access to financial support from appropriate government organization, poor infrastructure as well as corruption. This paper has vast implications for the rural herbal entrepreneurs as it gives insight into the reasons and factors that brought about failures and successes.
\end{abstract}

Keywords: entrepreneurship, herbal, success factors, technology implementation

\section{Introduction}

Entrepreneurship is becoming of vital importance in the economics like Malaysia and it is strongly related to small medium enterprises (SME) which is considered to be the main developing force of the developing economic market (Norhaiyati et al, 2011; Van Praag \& Versloot, 2007). Many economists believed earlier that it is the large firm which contributes in the developing of economics and quality of life in the country. But it has been changed when countries like Taiwan, Korea and Japan established this economics on the base of SMEs and they build up these economics from grass root level to the heights of the success. According to Schapper (2006), in developing nations more than $90 \%$ fall under the group of SMEs and these firms are microenterprises. Malaysia is also one of the countries focusing on the developing of entrepreneurship (Hamidon, 2009). Small medium enterprises are very heterogeneous business operating in many different sectors such as trade, agri-business, manufacturing (Hussain et al, 2009; Carree \& Roy, 2005). Herbal entrepreneurship in Malaysia has become another economic engine of growth and has the potential to become a significant industry in the Malaysian agriculture (Murray, 2011). In 1998 to 2010 the Third National Agricultural policy had identified herbal products natural products industry as new and future industry group. Malaysia herbal industry total value was estimated at RM4.55 billion in 1999.The herbal industry in 2005 has been identified as a new and future industry group with as a new and future industry group with an estimated market value of RM7.97 billion (Abu Kasim, 2007). Besides, Abdul Aziz (2003) mentioned that the key driving force for growth of the herbal industry in Malaysia are changes in life style the growing emphasis on health and growing cost of the synthetic medicines.

The diversity of genetic resources, excellent tropical climate, increasing research and development interest, increasing demand for natural products and indigenous knowledge put Malaysia as having a vast potential size in terms of herbal based market (Ibrahim, 2006; Jamai, 2006). However, until today, the herbal industry is facing numerous problems that include shortage of local raw materials, the lack of large-scale cultivation activities, domestic grading without the availability of standardized mechanization and its related technologies and lacking in skilled manpower to provide scientific evidence for health related claims (Hawa, 2011; Viduriati et al, 2012; Nordin et al, 2008). Despite these weaknesses, there are opportunities for development of new and improved products, development of new and improved processing technologies which herbal entrepreneurs could venture into government authorized good manufacturing practice (GMP) holder entrepreneurs(Ismail and Sulaiman, 
2007; Ellitan, 2002) and government authorized agents (such as Mardi and FRIM). It is evident that there is a huge potential in the herbal market but the involvement of local herbal entrepreneurship in Malaysia is still very low and in its infancy stage. Hence, this research is designed to indentify the critical success and failure factors of the rural herbal entrepreneurship in Malaysia.

\section{Methodology}

This study is a qualitative analysis, using in-depth interview among ten rural Malay herbal entrepreneurs. The interview focused on the respondent's opinion and perception of the barriers to the development of their entrepreneurship. During the interview, observation was also implemented. The primary source of data was the semi-structure in-depth interviews with the respondent. Each interview was semi-structured and guided by a set of open-ended questions, with a focus on their barriers to development for their entrepreneurship. The average interview time in each respondent was an hour to two hours. As was suggested by Yin (1994), the open-ended interviews were used to expand the depth of data gathering and to increase the number of source of information. In a case study research reliability deals with the ability of a different researcher to research the same conclusion if they did same case study. To help ensure the reliability, it is suggested that the research follows an established protocol and the data was categorized. The main reason to ensure the analysis relied on all the relevant evidence, it address the most significant aspects of the case study (Yin, 1994). It provided rich and thick description from the respondent, regarding their experience and perception of the backwardness of their herbal entrepreneurship. At the end, it helped to identify the entrepreneur's problems to meet the development stage of their herbal entrepreneurship.

\section{Results and Discussions}

For analysis of interview data, it was started with the coding process first. The transcribed interviews were read all in order to locate the relevant segments that corresponded with previous identified categories and to code them. Then parts of the relevant segments of data or quotations with their respective coding inserted in brackets were retyped and made bold. Then the differences and similarities between codes were checked and then these codes were categorized as their similarities. In the next step, analysis was carried out and looked how this coded concepts helped to get the answers of the questions posed. Descriptions of the respondents' information are as follows.

\subsection{Respondent 1 (R1): Puan Hjh Sharifah Samariah SD Ahmad}

Puan Hjh Sharifah Ahmad is 55 years of age, owner of the company "MILLIONS STAR" which is set up in Penang. It is a Malay traditional herbal medicine manufacturer in Malaysia led by a woman. She got her basic education from her village, in Penang. Her late father started herbal entrepreneurship in 1956 with the capital of RM10 and now after 55 years their capital increased to RM500K. It has a strong historical background as 55 years ago the present owner's father started this herbal business with a small capital.

At present, the company is running with 15 employees producing 15 products. The main products are traditional medicine, coffee and cosmetics. The raw materials of these productions are imported from overseas. The product has been selling only domestic market and because they do not have the GMP (good manufacturing practice) license they cannot go for overseas market. The production of this company is semi-automated with $30 \%$ manpower due to Malaysian's low wage rate and monthly sales are around RM100K since last year. The company did not sell products directly to the drug store. Selling is done through on-line internet marketing and government marketing support. The owner of this enterprise is very hard working and has a strong experience to develop the business. For financial problem, this entrepreneur is facing challenges to follow government new rules and regulation. The company needs government support for business development plan.

\subsection{Respondent 2 (R2): Mr. Hj Ahmad Ashraff Bin Hj.Khairi Jamal}

The entrepreneur's age is 60 and he started his business in 1987. The name of his company based in Kelantan is MINYAK MESTIKA. It is a Malay herbal company run by their family members. He is one of the successful herbal entrepreneurs in Malay community in Malaysia. Mr. Hj Ashraff was a former religious teacher in Kelantan and learnt this herbal business from his late parents. They have their own manufacturing facility .Few products of this company is a monopoly business in Malaysia and overseas market in Thailand, Brunei, Middle East and Indonesia. They need government full support on technical and financial sector to fulfill the company's development business plan.

\subsection{Respondent 3 (R3): Mr. Zeck Zaiddy}

Mr. Zaiddy has completed his STPM from Selangor. This herbal enterprise was established in 2000 at Taman Industry Lembah Jaya Ampang, Selangor run by his father. He took over this after father passed away. They 
have own sales agent in most of the states but sales is very poor because of unskilled marketing team. Total monthly sales now are between RM20K to $30 \mathrm{~K}$, and that is the reason they are trying to get the government loan for their business development plan.

\subsection{Respondent 4 (R4): Mr. Shaikh Ismail Bin Abdullah}

Mr. Ismail holds his chemical engineering degree in 1989 and while being a government servant in Malaysia he started his herbal entrepreneurship from his innovated herbal product located at Mentakab, Pahang. Due to government lack of support in financial and technical areas, until today he finds it difficult to achieve the developing stage on the herbal production. The monthly sales are very less for his low quality product compared to other herbal entrepreneurs among Malay community.

\subsection{Respondent 5 (R5): Encik Razzak}

His herbal entrepreneurship is located in lot 187, Kampung Seri Gemencheh, 73200, Gemencheh, Negeri Sembilan and he has few herbal products in the market but for low quality grade products and the sales are very low. That is why he requires immediate government fund and technical support to develop his herbal innovation products.

\subsection{Respondent 6 (R6): Mr. Mohd Rosli Bin Saidin}

Mr. Rosli is from Kelantan and the location of his company is at Mesra Bio Herb 2, Depan Zon Ria 2, Kawasan Perniagaan Teksi, 18500 Machang, Kelantan. This herbal entrepreneurship is run by a young couple since their parents passed away in 2000. Though they have only SPM certificate, but they always learn the present technology for the market demand. At present they are producing five own products and sales are around RM50K. They are facing challenges to develop their entrepreneurship due to financial and technical problem.

\subsection{Respondent 7 (R7): Mr. Abedin Bin Saleh}

He started his business since 2001 after his graduation in accountancy and information management. He is happy with his present business growth now after many years of struggle. In 2003, his monthly sale was between RM30K to RM50K which is very low. In 2005, the government has approved RM70K loan for his entrepreneurship development. He changed his marketing plan after he obtained the loan. He further mentioned "I was studying on a government scholarship in a local public university and I had friends from different ethnic groups such as Chinese, Indians and others. I learnt from them the entrepreneurial culture. From that day, I build up strong network among my different ethnic friends and this helped to increase my monthly sales to RM100K. I have six employees now and hopefully I will buy an auto-single machine for production unit next year from my business profit. From my previous experiences, now I can develop my entrepreneurship according to my business plan. Sorry to say, earlier I was fully dependent on government sales promotional plan and simply gave credit to the customers but now I am very strict when it comes to matters regarding payment."

\subsection{Respondent 8 (R8): Mr. Feros Bin Jamal}

Mr. Feros was born in Perak and this herbal business has been their generation business. After his father lost his two legs, he stopped schooling and took over the family's herbal entrepreneurship. His business started in 1998 and until 2005 was struggling financially to run the business. One of his relative lent him some money for a short period. Now he is a little stable but the government forced him to follow new rules and regulation which is a challenge for rural herbal entrepreneurs." He mentioned that "we need full financial, technical and human support immediately from the government to develop our herbal business. Otherwise, we have to shut down our family generation business".

\subsection{Respondent 9 (R9): Mr. Musa Hitam}

In the year 1995, Mr. Musa Hitam established his entrepreneurship business in Perlis after his father had encountered a loss in his business. Mr. Musa said, "My father was always busy to help the community and never kept any record about business loss or profit. That is the main reason we are now facing problem to run our herbal entrepreneurship. Finally, we managed to get some financial support from the government with the help of my cousin and now we have five products in the market, every month our sales are increasing. As you know we have limited knowledge on herbal production and as a result the government does not recognize and thus we cannot produce our products under our own brand. We need government approval in the future to produce our product in our own place with full monitoring processes such as training, marketing promotion support and finance. If this happens we can gradually develop our own product in our place and avoid from contract herbal manufacturer that will copy all our product compositions and eventually affect our business." 


\subsection{Respondent 10 (R10): Mr. Sulaiman Bin Hanafee}

Mr. Sulaiman is a successful entrepreneur among all the ten herbal entrepreneurs. His father was an Indian immigrant and mother from Indonesia and came to work here but after married they started small scale herbal business in 1985. Gradually, they did well from the beginning in their business because of hard work and always maintaining good financial record. His one son after graduation joined this entrepreneurship for development. Now their monthly sales range from RM200K to RM250K and they have now ten products in the market. They have agents from different ethnic groups and also export their products to Brunei, Saudi Arabia and Qatar. The son told "2015 we will move our new location which is now under construction. We are really happy but till now we need government financial support and training from time to time."

\subsection{The Cause of the Lack of Development of Malay Herbal Entrepreneurship}

Based on the respondent's data, five common factors were identified for the lack of entrepreneurship development and they are as follows.

\section{(a) Attitude and mindsets}

From the interview data, it was indentified that negative mindset is the main cause of the lack of development among Malay herbal entrepreneurs. Six respondents (R1, R2, R4, R6, F8 \& F9) felt that Malays have the attitude and mentality to get rich in an easy and quick way. Puan Hjh Shariffah and Encik Mohd Rosli Bin Saidin (R1, R6) said that "We find out that a lot of Malay have the tendency to make fast money instead of long run business. If they have the opportunity, they have the projects, is always a tendency to become rich faster. They do not want to go through the process of creating establishment."

Another negative attitude identified by four respondents as harmful to the development of Malay herbal entrepreneurship as Malays simply spend more money for personal life rather than their own business development. One comment by respondent Mr. Hj. Ahmad Ashraff Bin Hj Khairi Jamal (R2) illustrated that view:

"We always want to go for material things once make profit from business and forget to use this money into business".

In addition, Malay entrepreneurs also see that they have lower confidence in capacity to make more profit and bigger business plan as expressed by respondents R2, R3, R4, R6, R8 \& R9. Here is a view of respondent R4, R7 \& R10:

"Malays always like to do small scale business in own house and never show better capability".

Moreover, the attitude of Malay herbal entrepreneur is over dependent on the government, as if the government is responsible to provide them business and assistance. This is the cause for lack of progress in their entrepreneurship. Respondent R4, R7 \& R10 also said that most of their yearly selling depends on attending in various exhibitions in different places, which government arrange for them. They could not sell their products in open market as the supermarkets decline their products.

Regarding the skill and knowledge of Malay herbal entrepreneur respondents R1, R2, R3, R4, R6, R8 \& R9 agree that they lack in technology on using skill and lack of product marketing knowledge. This is the main reason, they could not penetrate into the supermarkets with their products and due to lack of technical skills, they are afraid to compete with others.

\section{(b) Lack of competitiveness of sustainability}

Lack of financial capability is the main problem of Malay herbal entrepreneur which is viewed by respondent R1, R2, R3, R4, R5, R6, R7, R8, R9 \& R10. All these respondents said that Malays have limited sources to borrow money except from commercial banks. This is shared by all the ten respondents:

"We have no extra source that will help our business".

Regarding the lack of finance and promising business, respondents R1, R3, R6, R8 \& R9 provided their view through a statement:

"From their business performance, Malays can't afford to do their business in a business zone because it is too expensive. Also they are facing challenges to follow the government new GMP guidelines due to finance."

In brief, because of their lack of capital and alternative financial assistance, many Malay herbal entrepreneurs are facing problems to develop their business. 


\section{(c) Lack of entrepreneurship culture}

Respondents R2, R3, R4, R6, R7 \& R9 said that Malays are reluctant to take business risks to open up their venture despite the potential higher returns and better prospects. This view is strongly expressed by respondents as follows:

"Malays will go to business area, where they are familiar and easy to make money-------they don't want to trade in areas that are not familiar. They don't want to take the risk".

On the other hand, respondents agree that the Malays are mostly an agriculture-oriented society. This is a concern as it is a reason why they are less capable in entrepreneurship. However, respondents R1, R7 \& R10 did not agree that the Malays are historically not business people.

\section{(d) Lack of cooperation and networking}

Respondents R1, R2, R3, R4, R5, R6, R7, R8, R9 \& R10 said that lack of networking among Malay herbal business has caused them to become less competitive as compared to others. Six respondents (R1, R2, R3, R4, R8 \& R9) said that they do not like to learn to work together and share their knowledge with others. Respondents R1, R2, R6, R7 \& R10 remarked:

"We are not interested to work together with other community friends or relatives and like to do individually even we face financial problem to run business also."

\section{(e) Entrepreneurial support and government policy}

In term of entrepreneurial support and government policy factors, R2, R3, R4, R5 said that role of government policy on their entrepreneurship activity sometimes affect negatively rather than positively. They said due to government's role on their activity, they could not do as their own plan. The government forces them to follow all the government's instruction. This is a problem they are facing but it is unknown to the government. Only R1, R6, R7 \&R10 respondents did not agree with the other respondents.

Based on the above responses and discussion, it displayed respondent's response on government policy and initiatives to promote Malay herbal entrepreneurship in Malaysia. These policies and initiative sometimes put the entrepreneurs in a fix, instead of moving forward. The government's initiative is not helping rural Malay herbal entrepreneurs much in terms of developing their business sustainability and their creativity and innovation. Rather, it makes the entrepreneurs to be dependent on government as well as lacking in initiative.

\section{Conclusion}

In conclusion, the study integrated the reasons for the failures of Malay herbal entrepreneurs in rural areas to develop their entrepreneurship. The findings of this research showed that both internal factors and external factors contributed to the lack of development among rural Malay herbal entrepreneurs. Among the internal factors are negative attitude and mindsets of Malay entrepreneurs, the absence of entrepreneurial culture within their society, the lack of cooperation and networking among the Malays, and the fear of failure. On the other hand, the external factors are lack of sustainability and competitiveness among Malay herbal business, and present government rules.

The findings identified that the government of Malaysia has made initiative plans to promote the Malay herbal entrepreneurs in development but most of them were not successful. From the findings of this study, it is understood that the major cause on the lack of development is inadequate financial support, to develop further rural herbal entrepreneur's manufacturing process is also related in following the government rules. In addition, it was also identified that if the Malay entrepreneurs do not develop their psychological behavior as entrepreneurs, they will be lagging behind with their business. Besides, the government needs to modify their rules to help directly rural Malay herbal entrepreneurs. If these steps were to be taken, rural herbal entrepreneurship will progress swiftly.

\section{References}

Abdul, A. R. (2003). Turning Malaysia into a global herbal producer: A personal perspective. Siri Syarahan Perdana Professor, University Technology Malaysia.

Carree, M., \& Roy, T. (2005). Understanding the role of entrepreneurship for Economic growth: Discussion paper on Entrepreneurship growth and Public Policy. Max Planck Institute for Research in to Economy Systems group entrepreneurship, Growth Germany.

Ellitan, L. (2002). Factors influencing the success of technology adoption: A case study of Indonesian manufacturing firms. Master's Thesis, Universitas Kristen Petra, Surabaya, Indonesia. 
Hamidon, S. (2009). Development of Malay Entrepreneurship in Malaysia. PhD thesis, Massey University, Auckland, New Zealand.

Hawa, Z. J. (2011). Growing Our Herbal Industry. Retrieved from http://pmr.penernagan.gov.my/index.php/sosial/11684

Hussain, I., Hussain, S., \& Si, S. (2009). Public partnership and SMEs opportunities. Paper presented at EUM-BIO Business Partnering Seminar, Matrade Exhibition and Conference Centre, Malaysia, 25 October 2007.

Ismail, R., \& Sulaiman, N. (2007). Technical efficiency in Malay manufacturing firms. International Journal of Business Society, 8(2), 24-37.

Ibrahim, J. (2006). The scientific values of Malaysian herbal Products. Malaysian Journal of Health Sciences, $4(1), 59-70$.

Jamai, A. J. (2006). Malay traditional medicine: An overview of scientific and technological progress. Asia-Pacific Tech Monitor.

Murray, H. (2011). Expanding the Malaysia herbal industry by developing the farmer-government University Nexus. Processing of the $7^{\text {th }}$ Malaysian Agro -Bio International Conference with the $12^{\text {th }}$ Malaysian International Food and Beverage Trade Fair, July 12-15, 2011, Putra World Trade Centre, Kuala Lumpur, Malaysia.

Nordin, N., Othman, S. N., \& Mat, R. C. (2008). Technology implementation barriers in the Malaysian herbal industry. A Case Study. Malaysian Management Journal, 12(1\&2), 79-88.

Norhaiyati, A. M., Nik, M. N., \& Md, Wan. Z. W. M. (2011). The influential factors in decision-making process among Malay woman entrepreneurs. The Institute for the Empowerment of Women Malaysia, Kuala Lumpur.

Schaper, M. T. (2006). Distribution pattern of small firms in developed economies: Is there an emergent global pattern? International Journal of Entrepreneurship and Small Business, 3(2), 183-189.

Van Praag, C., \& Versloot, P. (2007). What is the value of entrepreneurship? A review of recent research. Small Business Econ., 29, 351-388.

Viduriati, S., Golnaz, R., Zainal, A., Mad, N. S., \& Juwaidah, S. (2012). The motivational and social factors in predicting the intention of herbal-based entrepreneurs towards going green. UMT $11^{\text {th }}$ International Annual Symposium on Sustainability Science and Management 9th to 11th July 2012, University Malaysia Terengganu, Malaysia.

Yin, R. (1994). Case study research: Design and methods. Beverly Hills, CA: Sage Publishing.

\section{Copyrights}

Copyright for this article is retained by the author(s), with first publication rights granted to the journal.

This is an open-access article distributed under the terms and conditions of the Creative Commons Attribution license (http://creativecommons.org/licenses/by/3.0/). 